\title{
Investigating the Strength and Durability Properties of One- Way Slabs Incorporating Marble Dust as Cement Replacement Material
}

\author{
Muhammad Nauman Azhar ${ }^{1 a}$, Liaquat Ali Qureshi ${ }^{1 b}$, Muhammad Usman Rashid ${ }^{1 c}$
}

RECEIVED ON 15.07.2019, ACCEPTED ON 03.03.2020

\begin{abstract}
To reduce the environmental pollution caused by cement manufacturing and to save both the economy and resources, it is required to use alternative waste materials of pozzolanic nature to partially replace cement in the construction industry. Among different cement replacement materials being used now-a-days, marble dust is the one on which limited research has been done especially on the performance of structural members like RC slabs. In this paper, marble dust has been used in different ratios as partial replacement of cement in concrete mix. RC one-way slabs as well as plain concrete standard samples were cast to determine their mechanical properties i.e. compressive, tensile and flexural strengths, stiffness, first $\&$ ultimate load, crack patterns, modulus of elasticity, maximum deflection and durability etc. It was found that by increasing the dosage of marble dust in plain concrete samples, workability was decreased. Compressive and tensile strengths of concrete increased up to $7.5 \%$ replacement but decreased on further replacement. The permeability of concrete decreased with the addition of marble dust up to $10 \%$ replacement, then it increased. The behaviour of one-way slabs showed an increase in the first crack load and ultimate failure capacity. Moreover, decrease in the deflection of slabs was observed with the increasing replacement of cement with marble dust. The resistance of concrete against corrosion of steel reinforcement also increased due to less migration of chloride ions. Ultrasonic Pulse Velocity (UPV) tests showed improved homogeneity and stiffness of concrete structure with the replacement of cement by marble dust.
\end{abstract}

Keywords: RC One-Way Slabs, Cement-Marble Dust Replacement, Concrete Permeability, Compressive and Tensile Strength, Chloride Ion Migration, UPV, Modulus of Elasticity \& Flexural Strength, conomical \& Eco-friendly.

\section{INTRODUCTION}

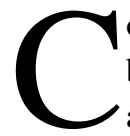
oncrete is a heterogeneous material in which binding material and aggregates are mixed in a definite ratio for a specific concrete grade, according to the required strength and use. In concrete mix, cement is a costly item as compared to other ingredients, thus cost of concrete mix mainly depends on the amount of cement used. In last ten years in Islamic Republic of Pakistan 392 million tonnes of Portland Cement was consumed [1]. According to "All
Pakistan Cement Manufacturers Association (APCMA)", the cement industry dispatched 4.24 million tonnes cement in April, 2018, 17.46\% higher than 3.58 million tonnes in April, 2017 [2]. At present, Pakistan has an estimated functioning capacity of cement production between 46 - 49 million tonnes per annum and by 2020 it is expected to increase up to 76 million tonnes per annum [3]. During the manufacturing of cement, a lot of soil pollution, water pollution and air pollution occurs [4]. Thus, in order to avoid such undesired effects of cement manufacturing

${ }^{1}$ Department of Civil Engineering, University of Engineering and Technology, Taxila, Pakistan.

Email: anauman.azharch@gmail.com (Corresponding Author), liaqat.qureshi@uettaxila.edu.pk, cm.usman@uettaxila.edu.pk

This is an open access article published by Mehran University of Engineering and Technology, Jamshoro under CC BY 4.0 International License. 
on economy and environment, it was needed to find some suitable cement replacer. In the past, a research was carried out in which furnace slag was used as a replacement of cement in concrete. The results stated that, furnace slag up to optimum dosage of $15 \%$ as replacement of cement, made the concrete immune to chloride and sulphates damages. Further addition, led to decrease in compressive, tensile and flexural strength of concrete [5]. Similarly, effect of utilizing waste marble dust as partial replacement of cement in concrete was also studied. The compressive strength and tensile strength of concrete increased up to $12.5 \%$ replacement of cement with waste marble powder, after that these decreased [6]. Sawdust concrete was also studied, in which waste sawdust was used as replacement of fine aggregates in concrete. The experimental results showed that, compressive and tensile strength of concrete decreased, as dosage of sawdust increased. However, decrease in unit weight of concrete was observed with the addition of sawdust [7].

Marble dust is one of the industrial solid waste materials that causes health problems and severely affects the environment [8]. Marble industry produces it from the processes of sawing, shaping, and polishing [9]. The generation of marble waste varies extensively from $30 \%$ in mechanized mines i.e. wire saw cutting methods to $65 \%$ at mines i.e. fracturing of rocks. The conventional techniques of extracting marble by blasting increases waste percentage by $60 \%$ to $70 \%$. During marble quarrying, this dust is generated that blankets the adjacent areas, causing vegetation die-off and badly disturbing the fertility of top soil [10]. Marble and Granite are the sixth largest mineral extracted in Pakistan. According to the Pakistan's Marble and Granite industry, it is estimated that 1.37 million tonnes of marble and granite were produced while $97 \%$ of it were consumed locally [11]. According to another estimate, there are 160.2 million tonnes of Marble reserves in the country out of which 98\% are in Khyber Pakhtunkhwa (KPK) a province in Pakistan. Granite reserves, only at one place in Northern areas shows a total of 414 million tonnes while other reserves of Granite are spread all over KPK, Baluchistan and Sindh [8]. Marble industry in Pakistan is flourishing day by day due to its massive use in both modern residential and commercial buildings. Thus, huge amount of solid wastes of marble would be generated by these industries that would also have an adverse effect on the environment in near future. As Pakistan is an under developed country, aim of this research was to consume the solid wastes of marble in concrete, owing to its binding properties and easily availability, in order to save the environment from air, land and water pollution caused mainly by these waste materials. To save the natural reservoirs of the country that are used in the manufacturing of cement and to produce cheaper, high strength, stiffer and durable green concrete.

The structural properties of concrete have also been examined in the past. However, the effect of marble dust as pozzolanic material in RCC one-way slabs in terms of its flexural strength, stiffness, durability against migration of chloride ions (corrosion of steel reinforcement), water permeability and economy was rarely discussed especially focusing on indigenous materials. This study focused on the improvement of physio-chemical properties of concrete with marble dust addition.

\section{MATERIALS}

\subsection{Cement}

Type-I Ordinary Portland Cement (OPC) was used in all batches of concrete mix. One of the most popular brands of the OPC in Pakistan is "Fauji Cement" which was used in this study. The chemical and physical properties of cement used are shown in Table 1.

\subsection{Fine aggregates}

Aggregates that pass through $4.75 \mathrm{~mm}$ sieve are fine aggregates, commonly called Sand. There are various types of sands found in Pakistan. However, "Lawrencepur Sand" was used in this research work. The sand was moist dried and free from impurities. The water absorption value of fine aggregates as found by AASHTO T-84 came out to be $1.55 \%$, specific gravity was determined as per AASHTO T-84 and found to be 2.70. Similarly, sand equivalent was calculated as 79.3 following the procedure given in

Mehran University Research Journal of Engineering and Technology, Vol. 40, No. 4, October 2021 [p-ISSN: 0254-7821, e-ISSN: 2413-7219] 
AASHTO T 176-86. Particle size distribution of fine aggregates is shown in Table 2 and corresponding curve is plotted in Fig. 1.
Oven dried weight of sample: $1,121 \mathrm{~g}$

Cumulative percentage retained: 256.4

Fineness modulus (FM): 256.4/100 = 2.564

\begin{tabular}{|c|c|c|c|c|}
\hline Sr. No & Parameter & Results & ASTM limits & Method \\
\hline \multicolumn{5}{|c|}{ Chemical characteristics } \\
\hline 1 & Loss on Ignition (LOI) & $2.0 \%$ & $3.0 \% \mathrm{Max}$ & \multirow[t]{9}{*}{ ASTM C-114 } \\
\hline 2 & Insoluble residue (IR) & $0.48 \%$ & $0.75 \% \mathrm{Max}$ & \\
\hline 3 & Sulphate $\left(\mathrm{SO}_{3}\right)$ & $4.0 \%$ & $3.0 \% \operatorname{Max}$ & \\
\hline 4 & Silica $\left(\mathrm{SiO}_{2}\right)$ & $21.1 \%$ & Not Specified & \\
\hline 5 & Alumina $\left(\mathrm{Al}_{2} \mathrm{O}_{3}\right)$ & $5.32 \%$ & - & \\
\hline 6 & Iron oxide $\left(\mathrm{Fe}_{2} \mathrm{O}_{3}\right)$ & $3.68 \%$ & - & \\
\hline 7 & Lime $(\mathrm{CaO})$ & $62.6 \%$ & - & \\
\hline 8 & Magnesia $(\mathrm{MgO})$ & $1.70 \%$ & $6.0 \% \operatorname{Max}$ & \\
\hline 9 & Sulfuric anhydride $\left(\mathrm{SO}_{3}\right)$ & $2.44 \%$ & $3.0 \% \operatorname{Max}$ & \\
\hline \multicolumn{5}{|c|}{ Physical characteristics } \\
\hline 1 & $\begin{array}{l}\text { Fineness by Blaine's air } \\
\text { permeability method }\end{array}$ & $2,915 \mathrm{~cm}^{2} / \mathrm{g}$ & $2,600 \mathrm{~cm}^{2} / \mathrm{g}$ Min & ASTM C-204 \\
\hline 2 & Initial setting time & 150 Min & $45 \min$ Max & ASTM C-191 \\
\hline 3 & Final setting time & $195 \mathrm{Min}$ & $375 \min$ Max & ASTM C-191 \\
\hline 4 & Autoclave expansion & $0.004 \%$ & $0.80 \%$ Max & ASTM C-151 \\
\hline 5 & $\begin{array}{l}\text { Compressive strength } \\
\text { 7-days }\end{array}$ & 3,148 Psi & 2,760 Psi Min & ASTM C-109 \\
\hline
\end{tabular}

\begin{tabular}{|c|c|c|c|c|c|}
\hline \multicolumn{6}{|c|}{ Table 2: Particle size distribution of fine aggregates (AASHTO T- 27) } \\
\hline $\begin{array}{c}\text { BS } \\
\text { Size }(\mathrm{mm})\end{array}$ & $\begin{array}{c}\text { ASTM } \\
\text { Sieve No. }\end{array}$ & $\begin{array}{c}\text { Cumulative } \\
\text { retained } \\
(\text { grams })\end{array}$ & $\begin{array}{c}\text { Retained } \\
(\% \text { age })\end{array}$ & $\begin{array}{c}\text { Passing } \\
(\% \text { age })\end{array}$ & $\begin{array}{c}\text { Specifications for } \\
\text { passing limits } \\
(\% \text { age })\end{array}$ \\
\hline 9.5 & $3 / 8 \%$ & 0 & 0 & 100 & 100 \\
\hline 4.75 & $\# 4$ & 40.4 & 3.6 & 96.4 & $95-00$ \\
\hline 2.36 & $\# 8$ & 161.4 & 14.4 & 85.6 & - \\
\hline 1.18 & $\# 16$ & 250.0 & 22.3 & 77.7 & $45-85$ \\
\hline 0.600 & $\# 30$ & 590.7 & 52.7 & 47.3 & - \\
\hline 0.300 & $\# 50$ & 810.4 & 72.3 & 27.7 & $10-30$ \\
\hline 0.150 & $\# 100$ & $1,021.0$ & 91.1 & 8.9 & $2-10$ \\
\hline 0.075 & $\# 200$ & $1,089.6$ & 97.2 & 2.8 & $0-3$ \\
\hline
\end{tabular}

\subsection{Coarse Aggregates}

Aggregates retained on $4.75 \mathrm{~mm}$ sieve size are named as coarse aggregates. Coarse aggregates were selected as per ASTM C 33 - 03. Aggregates were acquired from local query known as "Margalla Crush". The source of Margalla crush is in the north of Islamabad, the capital of Pakistan. For compact mix of concrete, two different sizes of the coarse aggregate were used i.e. $20 \mathrm{~mm}$ down and $10 \mathrm{~mm}$ down. The blend of concrete was prepared by using $80 \%$ by weight of 20 $\mathrm{mm}$ down sized aggregates and $20 \%$ by weight of 10 $\mathrm{mm}$ down sized aggregates. The water absorption value of coarse aggregates found by AASHTO T-85 came out to be $0.83 \%$. Specific gravity was determined as 2.70 as per AASHTO T- 85 and sand equivalent was calculated as 79.3 by following the AASHTO T 176-86. Particle size distribution of 


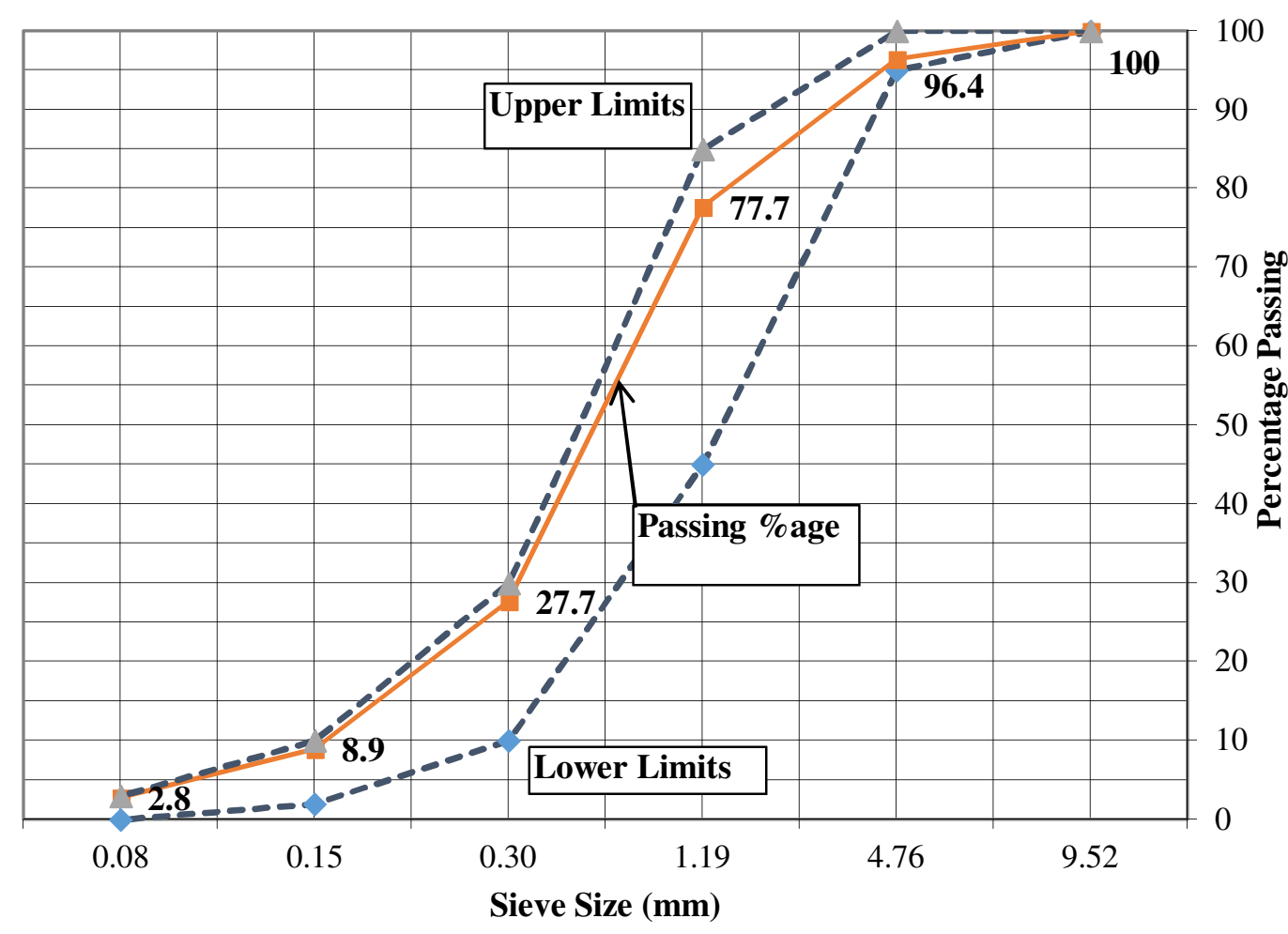

Fig. 1: Particle size distribution curve of fine aggregates (AASHTO T- 27)

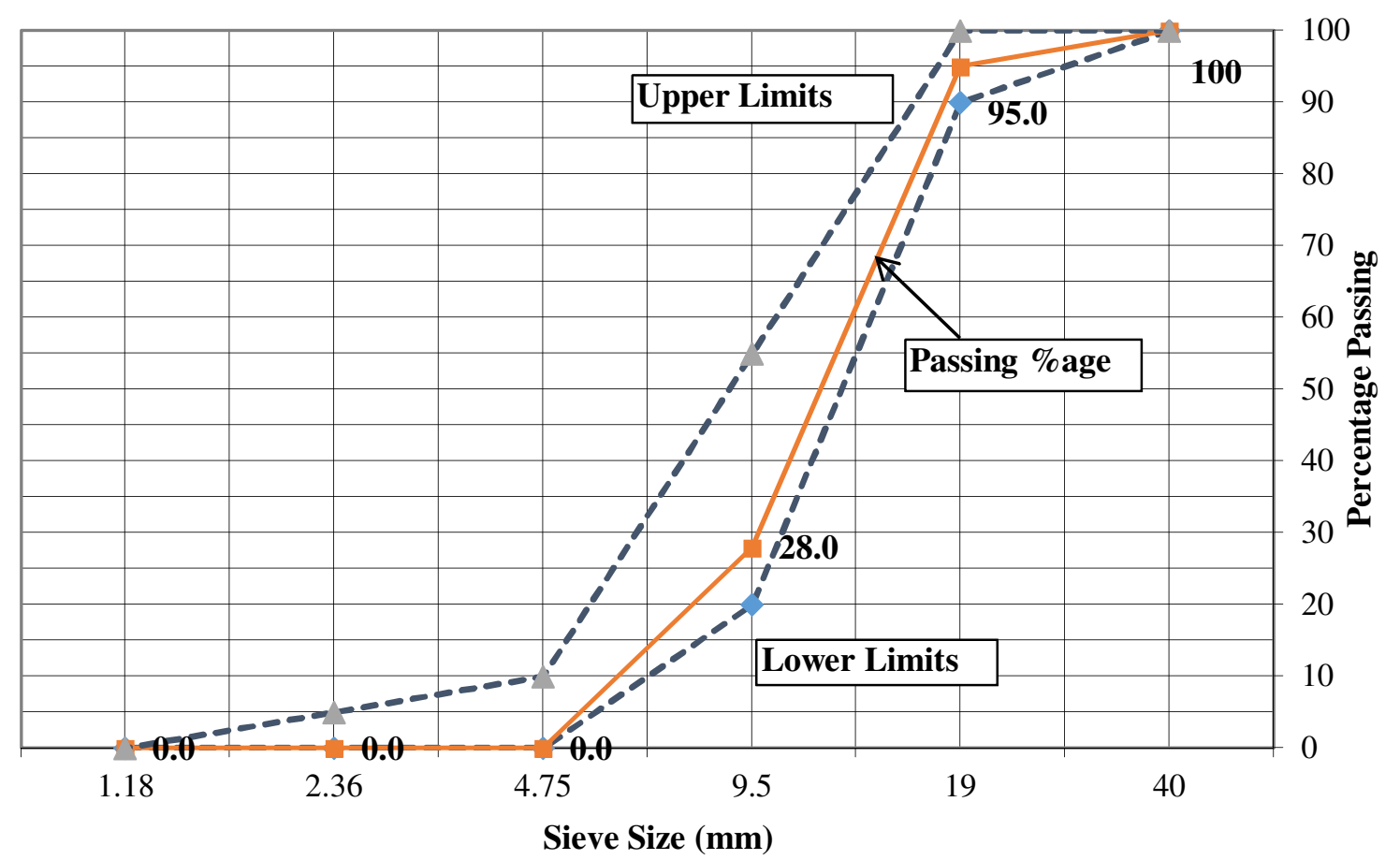

Fig. 2: Particle size distribution curve of coarse aggregates (AASHTO T- 27) 


\begin{tabular}{|c|c|c|c|c|c|}
\hline \multicolumn{6}{|c|}{ Table 3: Particle size distribution of coarse aggregates (AASHTO T- 27) } \\
\hline $\begin{array}{c}\text { BS } \\
\begin{array}{c}\text { Sieve size } \\
(\mathrm{mm})\end{array}\end{array}$ & $\begin{array}{c}\text { ASTM } \\
\text { Sieve No. }\end{array}$ & $\begin{array}{c}\text { Cumulative } \\
\text { retained } \\
(\text { grams })\end{array}$ & $\begin{array}{c}\text { Retained } \\
(\% \text { age })\end{array}$ & $\begin{array}{c}\text { Passing } \\
(\% \text { age })\end{array}$ & $\begin{array}{c}\text { Specifications for } \\
\text { passing limits } \\
(\% \text { age })\end{array}$ \\
\hline 80 & - & - & $0 \%$ & $100 \%$ & 100 \\
\hline 40 & $\# 3$ & 250.0 & $5.0 \%$ & $95 \%$ & $90-100$ \\
\hline 19.0 & $3 / 4 \%$ & $2,000.0$ & $40.0 \%$ & $60 \%$ & - \\
\hline 9.5 & $3 / 8^{\prime}$, & $3,600.0$ & $72.0 \%$ & $28 \%$ & $20-55$ \\
\hline 4.75 & $\# 4$ & $5,000.0$ & $100.0 \%$ & $0 \%$ & $0-10$ \\
\hline 2.36 & $\# 8$ & $5,000.0$ & $100.0 \%$ & $0 \%$ & $0-5$ \\
\hline 1.18 & $\# 16$ & $5,000.0$ & $100.0 \%$ & $0 \%$ & - \\
\hline
\end{tabular}

\begin{tabular}{|c|c|c|c|}
\hline \multicolumn{2}{|c|}{ Table 4: Chemical parameters of water } \\
\hline Sr. No & Parameter & $\begin{array}{c}\text { Content } \\
(\mathrm{ppm})\end{array}$ & $\begin{array}{c}\text { B.S. 3148 limits } \\
(\mathrm{ppm})\end{array}$ \\
\hline 1 & Total Alkalinity as $\mathrm{CaCO}_{3}$ & 91.20 & $<1000$ \\
\hline 2 & Sulphate as SO4- & 17.86 & $<1000$ \\
\hline 3 & Organic matter & 110.28 & - \\
\hline 4 & Total dissolved solids & 267.11 & $<2000$ \\
\hline 5 & Chlorides $\left(\mathrm{Cl}^{-1}\right)$ & 72.78 & $<500$ \\
\hline
\end{tabular}

\begin{tabular}{|c|c|c|c|c|c|c|c|}
\hline \multicolumn{7}{|c|}{ Table 5: Specifications of steel reinforcement used (ASTM 615/A 615M - 00) } \\
\hline $\begin{array}{c}\text { Sr. } \\
\text { No }\end{array}$ & $\begin{array}{c}\text { Imperial } \\
\text { bar size. }\end{array}$ & $\begin{array}{c}\text { Exact dia } \\
\text { (Inches) }\end{array}$ & $\begin{array}{c}\text { Weight } \\
(\mathrm{lb} / \mathrm{ft})\end{array}$ & $\begin{array}{c}\text { Area } \\
\left(\mathrm{In}^{2}\right)\end{array}$ & $\begin{array}{c}\text { Yield } \\
\text { strength } \\
(\mathrm{psi})\end{array}$ & $\begin{array}{c}\text { Ultimate } \\
\text { strength (psi) }\end{array}$ & $\begin{array}{c}\text { Elongati } \\
\text { on } \\
(\%)\end{array}$ \\
\hline 1 & $\# 3$ & 0.380 & 0.386 & 0.113 & 71,385 & 111,043 & 14.06 \\
\hline 2 & $\# 4$ & 0.493 & 0.650 & 0.191 & 72,931 & 110,573 & 14.06 \\
\hline
\end{tabular}

coarse aggregates is given in Table 3, while the corresponding curve is plotted in Fig. 2.

\subsection{Water}

Water is an essential component for making up of concrete because it actively contributes within the chemical process with cement. The thumb rule for using water is that, if it is drinkable then it can be safely use in the concrete mix. Thus, normal tap water sample was first chemically tested from the laboratory and then used for the purpose of casting as well as moist curing of all specimens. The properties of water used are given in Table 4.

\subsection{Steel Reinforcement}

Steel reinforcement used in this study was "Cold Twisted Deformed Steel Bars" one of the famous brands of Pakistan named "Pakistan Steel". Two different diameters of steel i.e. $10 \mathrm{~mm}$ and $12 \mathrm{~mm}$ were used and their specifications and testing results are given in Table 5.

\subsection{Marble dust}

Marble dust was obtained from the local marble industry near Margalla Hills, Islamabad, Pakistan. The dust was obtained in purified form, as it is easily available both in raw and purified form in the local market. The sample material was tested in the laboratory for its physical and chemical properties. After testing, marble dust was sieved through $30 \mu \mathrm{m}$ sieve and then used in the concrete mix in different dosages as cement replacement. The physical and chemical parameters of marble dust are shown in Table 6. 


\begin{tabular}{|c|c|c|}
\hline \multicolumn{3}{|c|}{$\begin{array}{c}\text { Table 6: Physical and Chemical parameters of } \\
\text { Marble Dust }\end{array}$} \\
\hline $\begin{array}{l}\text { Sr. } \\
\text { No }\end{array}$ & Chemical parameter & $\begin{array}{l}\text { Marble dust } \\
\text { composition }\end{array}$ \\
\hline 1 & Silica $\left(\mathrm{SiO}_{2}\right)$ & $1.83 \%$ \\
\hline 2 & Alumina $\left(\mathrm{Al}_{2} \mathrm{O}_{3}\right)$ & $0.56 \%$ \\
\hline 3 & Iron oxide $\left(\mathrm{Fe}_{2} \mathrm{O}_{3}\right)$ & $0.24 \%$ \\
\hline 4 & Lime $(\mathrm{CaO})$ & $52.34 \%$ \\
\hline 5 & Magnesia $(\mathrm{MgO})$ & $1.08 \%$ \\
\hline 6 & Sulphate $\left(\mathrm{SO}_{3}\right)$ & $0.07 \%$ \\
\hline 7 & $\mathrm{~K}_{2} \mathrm{O}$ & $0.17 \%$ \\
\hline 8 & $\mathrm{Na}_{2} \mathrm{O}$ & $0.01 \%$ \\
\hline 9 & Chlorides $\left(\mathrm{Cl}^{-1}\right)$ & $0.4 \mathrm{mg} / \mathrm{g}$ \\
\hline 10 & $\begin{array}{l}\text { Loss on Ignition } \\
\text { (LOI) }\end{array}$ & $42.23 \%$ \\
\hline 11 & Blaine & $102.1 \mathrm{~m}^{2} / \mathrm{kg}$ \\
\hline 12 & Moisture content & $0.2 \%$ \\
\hline 13 & $\mathrm{pH}$ & 7.86 \\
\hline 14 & Color & White \\
\hline
\end{tabular}

\subsection{Chemical Admixture}

Chemical admixtures are the material apart from the aggregates, water and cement, add to the concrete mix to enhance its performance. Chemrite $520 \mathrm{BA}$ organic polymer blend, the most commonly used water

reducing and set retarding concrete admixture was used in this study. The technical parameters of the admixture are explained in Table 7.

\begin{tabular}{|c|c|c|}
\hline \multicolumn{3}{|c|}{ Table 7: Technical parameters of admixture } \\
\hline $\begin{array}{c}\text { Sr. } \\
\text { No }\end{array}$ & Technical parameter & Approx. Value \\
\hline 1 & Density at $25^{\circ} \mathrm{C}$ & $1.18 \mathrm{Kg} / \mathrm{ltr}$ \\
\hline 2 & $\mathrm{pH}$ value & 7.0 \\
\hline 3 & Chloride content & Nil (EN 934-2) \\
\hline 4 & Toxicity & Non-Toxic \\
\hline
\end{tabular}

\section{EXPERIMENTAL PROGRAMME}

ACI 211.1-91 (Absolute volume method) for the finalization of mix design was employed in this study [12]. Water cement $(w / c)$ ratio was set constant as 0.45 , to improve the consistency and workability of the fresh concrete. Superplasticizer was added in the mix@1\% of the total weight of cement used. The control mix was obtained by making the blend mix of 1:2:4 (Cement: Sand: Aggregate) concrete having specified characteristic compressive strength at moist curing age of 28 days was $22.9 \mathrm{MPa}$. The control mix was then compared with concrete containing marble dust partially replaced with cement.

Seven RCC one-way slabs with span ratio (longer dimension/shorter dimension) of 2.7 were cast. Plywood sheet formwork was designed and steel reinforcement mesh was tied using binding wires. Steel reinforcement mesh was placed in the formwork and concrete was poured in it. During the pouring, continuously rodding was done to remove air voids and to have better compaction. Surface finishing of the slab specimens was done using trowel. After 24 hours, all slab specimens were cured using hazencloth. At the moist curing age of 28 days, all slab specimens were white washed with white lime to easily mark the crack patterns. Loading platform was finalized following ASTM C 293-02, to determine its flexural response in terms of deflection, ultimate failure and crack pattern against the applied load.

The arrangement consists of RCC one-way slab with two longer sides supported. Load was applied with the help of jack at the centre of the slab. A load dial gauge was installed at the top of the jack for measuring the applied load. Arrangement for the application of the centre point loading was done [12, 13]. Strain gauges and LVDT were attached to the bottom of the slab specimens and load was applied in intervals. Cracks in the slabs produced against the applied load were noticed and marked with ink. The reinforcement \& casting details and loading arrangement have been shown in Fig. 3, 4 and 5.

Following properties of plastic and hardened concrete were investigated under this experimental programme:

1. Workability of concrete under "Slump Loss Test (ASTM C 143)".

2. "Compressive Strength under (ASTM C 39/C 39M-03)" and "Split Tensile Strength under (ASTM C 496/C 496M-04)".

3. Permeability of concrete under "Automatic Concrete Water Permeability Test (DIN 1048)".

4. Durability of concrete against the migration 

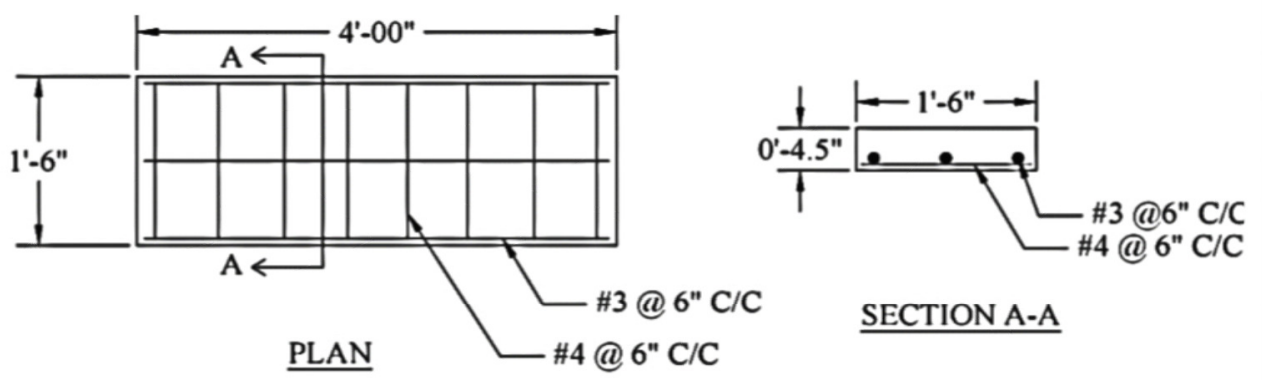

$\underline{\text { SECTION A-A }}$

Shorter Dimension (12mm) 8 Nos.

Longer Dimension (10mm) 3 Nos.

Spacing C/C 6"

Clear Cover 0.75"

Fig. 3: Reinforcement plan and x-section of RC one-way slab

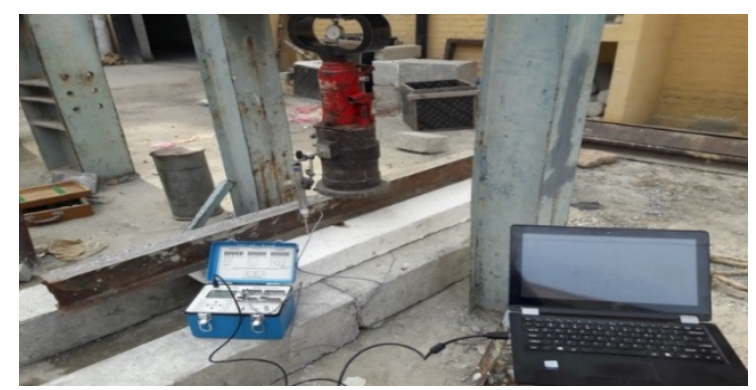

Fig. 4: Casting of RC Slabs

pattern of the Reinforced Cement Concrete (RCC) one-way slabs under "Center Point Loading Test (ASTM C 293-02)”.

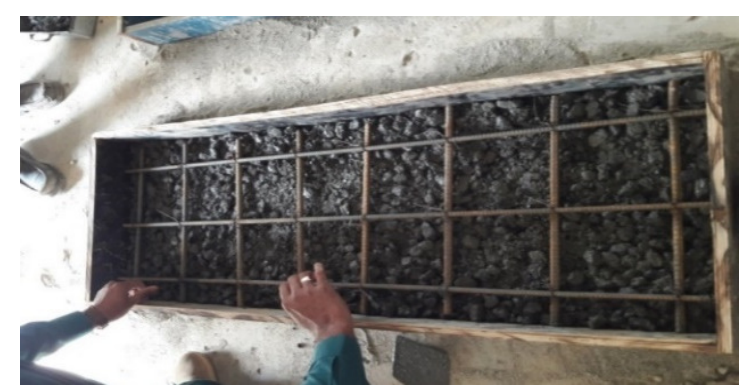

Fig 5: Centre point regarding test setup ASTM C 293-2

The detail of the tests performed and specimens casted is shown in Table 8.

\begin{tabular}{|c|c|c|c|c|c|c|c|}
\hline \multicolumn{8}{|c|}{ Table 8: Detail of the tests performed and specimens casted } \\
\hline $\begin{array}{l}\text { Sr. } \\
\text { No }\end{array}$ & $\begin{array}{l}\text { Specimen } \\
\text { code }\end{array}$ & $\begin{array}{c}\text { Cement } \\
\text { replacement } \\
\text { by marble } \\
\text { dust }\end{array}$ & $\begin{array}{l}\text { Cylinder } \\
\text { specimensfor } \\
\text { compressive } \\
\text { strength } \\
\text { (No) }\end{array}$ & $\begin{array}{c}\text { Cylinder } \\
\text { specimens } \\
\text { for tensile } \\
\text { strength } \\
\text { (No) }\end{array}$ & $\begin{array}{c}\text { Cube } \\
\text { specimens for } \\
\text { water } \\
\text { permeability } \\
\text { (No) }\end{array}$ & $\begin{array}{c}\text { RCC one- } \\
\text { way-slab } \\
\text { specimens } \\
\text { (No) }\end{array}$ & $\begin{array}{c}\text { Slab } \\
\text { specimensfor } \\
\text { chloride } \\
\text { migration } \\
(\mathrm{No})\end{array}$ \\
\hline 1 & $\mathrm{~S} 1$ & $0 \% \mathrm{MD}$ & 3 & 3 & 2 & 1 & 2 \\
\hline 2 & $\mathrm{~S} 2$ & $2.5 \% \mathrm{MD}$ & 3 & 3 & 2 & 1 & 2 \\
\hline 3 & S3 & $5.0 \% \mathrm{MD}$ & 3 & 3 & 2 & 1 & 2 \\
\hline 4 & S4 & $7.5 \% \mathrm{MD}$ & 3 & 3 & 2 & 1 & 2 \\
\hline 5 & S5 & $10.0 \% \mathrm{MD}$ & 3 & 3 & 2 & 1 & 2 \\
\hline 6 & S6 & $12.5 \% \mathrm{MD}$ & 3 & 3 & 2 & 1 & 2 \\
\hline 7 & S7 & $15.0 \% \mathrm{MD}$ & 3 & 3 & 2 & 1 & 2 \\
\hline \multicolumn{3}{|c|}{ Total no. of specimens casted } & 21 & 21 & 14 & 07 & 14 \\
\hline
\end{tabular}




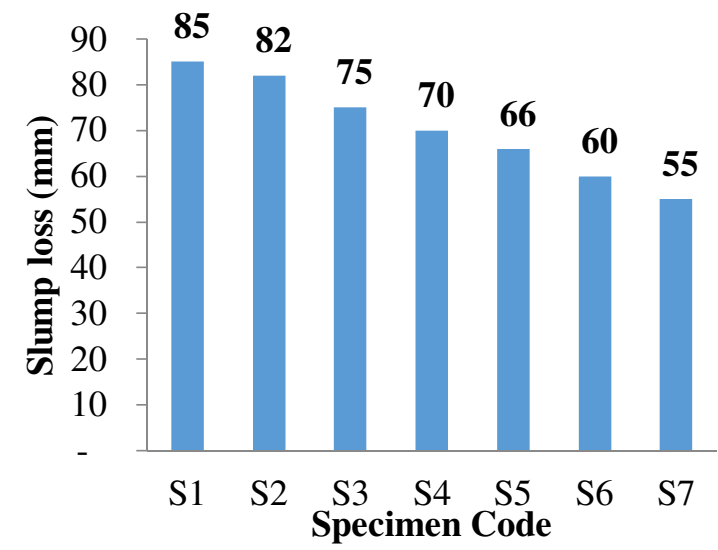

Fig. 6: Slump loss result of all concrete mixes

\section{RESULTS AND DISCUSSIONS}

\subsection{Slump test}

During the casting of specimens, slump test for each mix of concrete was performed and their results are plotted in Fig. 6. From the graph it can be seen that, there is decrease in the workability of concrete with increase in the dosage of marble dust. Maximum slump loss of $85 \mathrm{~mm}$ was observed in control mix S1 (0\% MD) and minimum slump loss was $55 \mathrm{~mm}$ in $\mathrm{S} 7$ (15\% MD). The workability of concrete decreased up to $35 \%$ in S7 (15\% MD) as compared to S1. Marble dust particles have more surface area, due to which it absorbed more water that resulted in decrease of workability of concrete [9].

\subsection{Compressive Strength}

For each mix, three cylinders of dimension $\mathrm{D} \times \mathrm{L}$ $(152.5 \mathrm{~mm} \times 304.8 \mathrm{~mm})$ were cast, following the mix design. Water cement ratio (w/c) was kept constant as 0.45 for all specimens. Total 21 cylinder specimens were casted and then tested under compression according to ASTM C 39/C 39-03 [14, 17]. Proper compaction was done by the use of vibrating table as well as rodding. The cylindrical concrete specimens were allowed to dry for 24 hours and then demoulded and submerged in the curing tank. After 28 days of curing, cylinder specimens were removed from the curing tank and dried with the towel and then tested under Uni-Axial Compression Testing Machine of $1,500 \mathrm{KN}$ capacity. The rate of the loading was kept as $0.25 \pm 0.05 \mathrm{MPa} / \mathrm{s}$. The failure pattern of pecimens after compressive strength test has been shown in Fig. 7 and results of compressive strength test are plotted in Fig. 8.

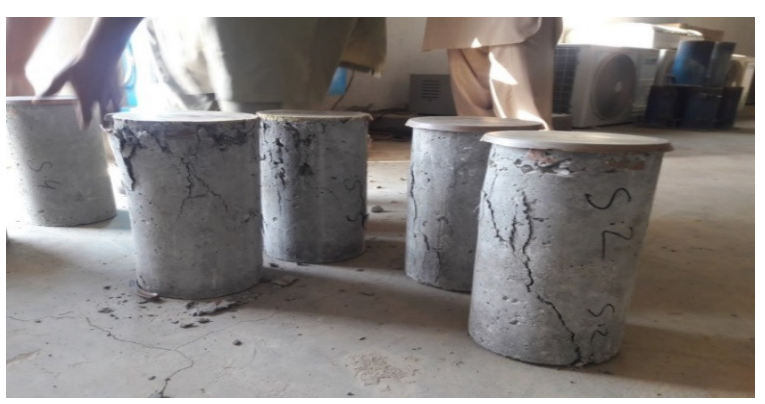

Fig. 7: Cylinder Specimens failure after compression test

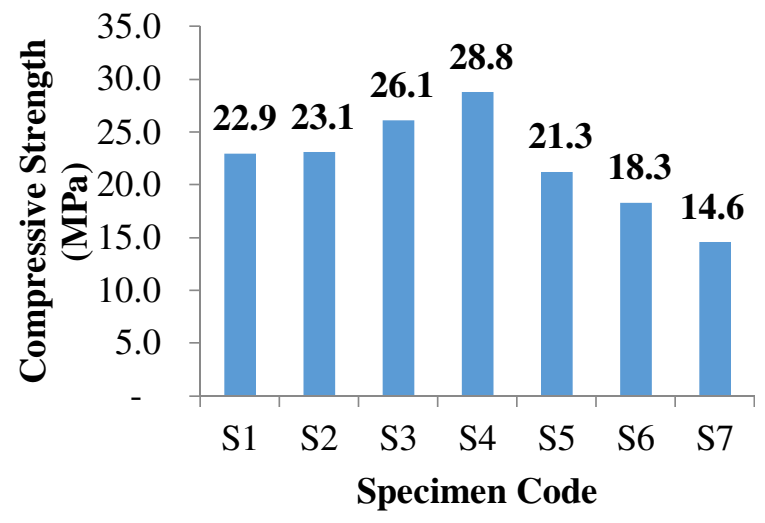

Fig. 8: Compressive Strength Result of all Concrete Mixes

As dosage of marble dust in concrete was increased, compressive strength first increased up to S4 (7.5\% $\mathrm{MD})$, then decreased. The compressive strength of S1 $(0 \%$ MD) was $22.9 \mathrm{MPa}$, where maximum compressive strength of S4 (7.5\% MD) was $28.8 \mathrm{MPa}$. There was $27 \%$ increase in the compressive strength up to $7.5 \%$ replacement of cement with marble dust, after that decrease in compressive strength was observed. Owing to the filler properties of marble dust, it filled the voids that resulted in stronger bonding between aggregates and binding material and ultimately resulted in increased compressive strength of concrete. 


\subsection{Split Tensile Strength}

Three cylinders of dimension $152.5 \mathrm{~mm}$ x $304.8 \mathrm{~mm}$ were cast for each mix, following the mix design. Water cement ratio (w/c) was kept constant as 0.45 for all specimens. Total 21 cylinder specimens were cast for determining the split tensile strength of concrete as per ASTM C 496/C 496 M-04, following the same procedure as adopted in case of compressive strength. The results of split tensile strength of concrete are shown in Fig. 9.

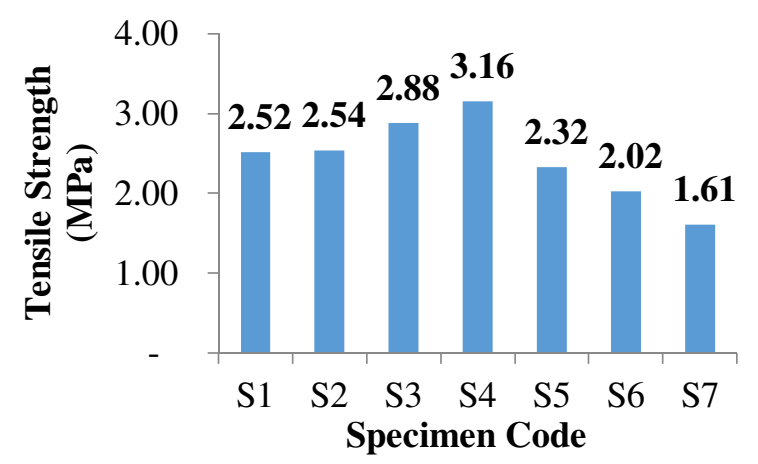

Fig. 9: Split tensile strength result of all concrete mixes

Tensile behaviour of concrete followed the same pattern as in case of compressive strength. There was $25 \%$ increase in tensile strength of concrete up to $7.5 \%$ replacement of cement with marble dust in S4 $(7.5 \%$ $\mathrm{MD})$. After that, decrease in tensile strength was observed.

\subsection{Concrete Water Permeability}

Two concrete cubes of dimension $152.5 \mathrm{~mm} \times 152.4$ $\mathrm{mm}$ were cast for each mix. In this way, total 14 cubes were cast for determining the water permeability through concrete. After 28 days curing, cubes were dried and all sides were painted with synthetic paint except top and bottom sides. Water permeability test on concrete was carried out according to German standard DIN 1048. Water Pressure was applied with water tank that was connected to an air compressor with adjustable pressure valve. The pressure was adjustable from 0 to 30 bars. The hydrostatic pressure was applied on cube specimens for a time period of 600 seconds. Water permeated through cube specimen was directly collected and measured into a graduated cylinder. The permeability co-efficient was calculated according to the Formula (A). The water permeability test apparatus and their results are shown in Fig. 10 and Fig. 11 respectively.

$\mathrm{K}=\frac{\mathrm{cc} \times \mathrm{h}}{\mathrm{A} \times \mathrm{t} \times \mathrm{P}}$

Where

cc: Water permeated through specimen $\left(\mathrm{cm}^{3}\right)$

P: Hydrostatic pressure in ( $\mathrm{cm}$. of water column) h: Specimen height $(\mathrm{cm})$

A: Specimen surface area $\left(\mathrm{cm}^{2}\right)$

$\mathrm{t}$ : Penetration time (sec.)

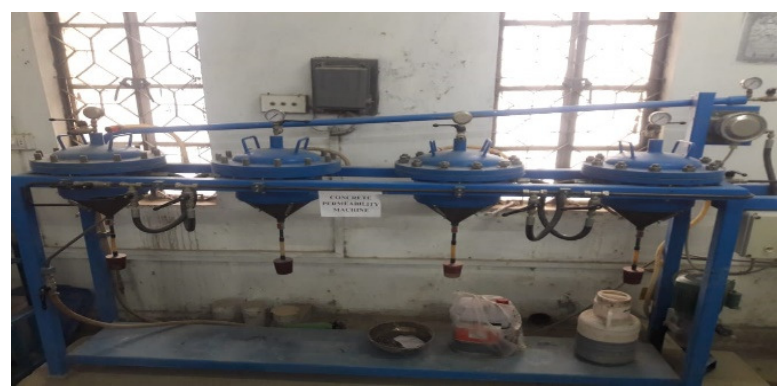

Fig. 10: Concrete water permeability apparatus

Up to $10 \%$ replacement of cement with marble dust in $\mathrm{S} 5$, porosity of concrete was decreased due to less voids and tight packing of aggregates with the binding material. In S5, decrease in permeability was $31 \%$ as compared to control mix. However, further increase in replacement of cement with marble dust resulted in increase of permeability due to poor packing.

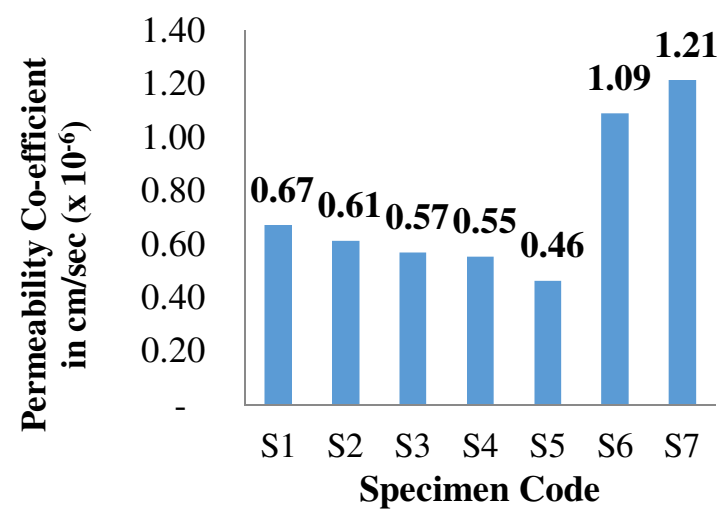

Fig. 11: Concrete water permeability result of all concrete mixes 


\subsection{RCC One-Way Slabs}

\subsubsection{First crack load}

After the application of load, cracks in flexure started to appear on the slab. The load against which the first crack on the slab appeared was noted down for all specimens. The graph given in Fig.12 shows the comparison of first crack load of all slab specimens.

The first crack load taken by control slab S1 (0\% MD) was $67 \mathrm{KN}$, but on increasing the dosage of marble dust, first crack load was also increased as compared to control slab. The maximum first crack load was observed in $\mathrm{S} 4(7.5 \% \mathrm{MD})$ as $90 \mathrm{KN}$. Load bearing capacity of slabs increased up to $34 \%$ by $7.5 \%$ cementmarble dust replacement. Further addition of marble dust led to the decrease in load bearing capacity. The reason for high first crack load was due to tight packing of binding material with the aggregates.

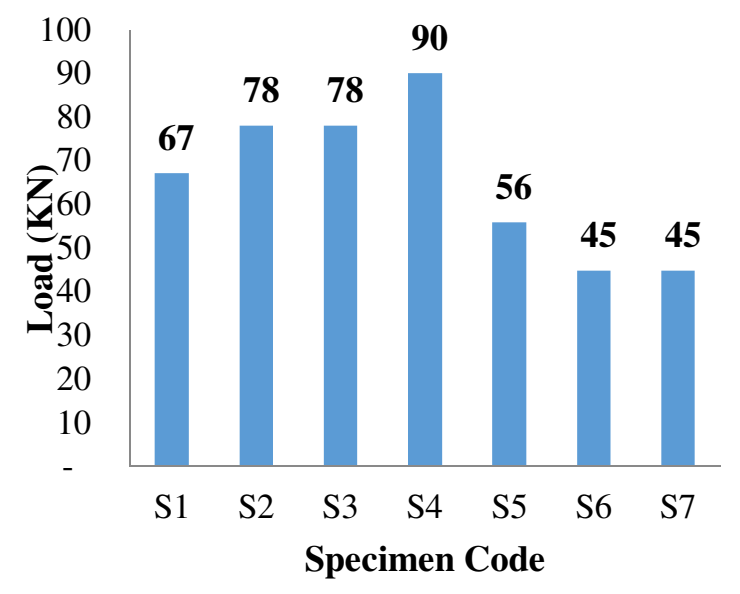

Fig. 12: First crack load of RCC slab specimens

\subsubsection{Ultimate load}

When loading was further increased, cracks started to appear on the bottom and sides of slab specimens resulted in the final failure of slabs. The load at this stage was declared as ultimate crack load and is shown in Fig. 13 for all slab specimens. Both flexural and shear failures were observed in all slab specimens.

The ultimate load taken by control slab S1 (0\% MD) was $213 \mathrm{KN}$ and the maximum ultimate load in S4 (7.5\% MD) was $269 \mathrm{KN}$. The ultimate load carrying

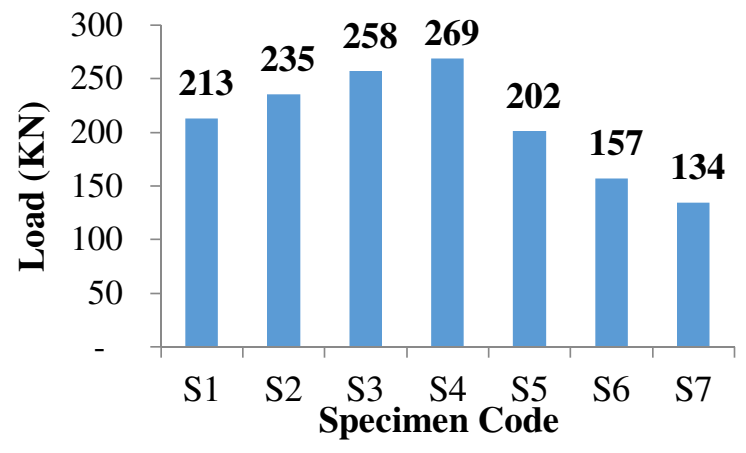

Fig. 13: Ultimate Load of RCC Slab Specimens

capacity of RC slabs increased up to $26 \%$ as compared to S1 (control slab), by replacing $7.5 \%$ cement with marble dust. It improved the bond strength and more energy was required to break the transition zone, that resulted in higher ultimate load value. Further addition led to the decrease in ultimate load capacity in S5 (10\% MD), S6 (12.5\% MD) and S7 (15\% MD).

\subsubsection{Stress-Strain Behaviour}

Stress verses linear strain behaviour of slab specimens was observed by attaching linear strain gauges with it. With the increase in the applied stress, linear strain in all slab specimens also varied. The trend of stress verses linear strain of all one-way slab specimens is shown in Fig. 14.

Stress verses linear strain behaviour followed a definite pattern and could be defined in terms of modulus of elasticity from Fig. 15. Greater the value of modulus of elasticity, greater would be stiffness of structure and vice versa. In S1 (control slab), modulus of elasticity was calculated as $6.2 \mathrm{MPa}$. In S2 $(2.5 \%$ MD) there was $4 \%$ increase in the modulus of elasticity as $6.5 \mathrm{MPa}$, more than the control slab. Further increase in the dosage of marble dust in S3 (5\% MD) resulted in increase in the modulus of elasticity as 6.9 MPa. Maximum modulus of elasticity was $7.8 \mathrm{MPa}$ in $\mathrm{S} 4$ (7.5\% MD), after that it decreased in S5 (10\% MD), S6 (12.5\% MD) and S7 (15\% MD).

\subsubsection{Load-deflection behavior}

Deflections in one-way slabs against the load were measured by LVDT. The behaviour of all RCC slab specimens against the applied load fell in three stages.

Mehran University Research Journal of Engineering and Technology, Vol. 40, No. 4, October 2021 [p-ISSN: 0254-7821, e-ISSN: 2413-7219] 
The first stage was elastic stage. In this stage, the load verses deflection graph is linear. The second stage was crack propagation stage. In this stage, the load verses deflection graph is nonlinear. The third stage was ultimate failure stage. In this stage, the maximum deflection values were recorded against the applied load till the failure of slab in flexural. The maximum deflection and load verses deflection behaviour of all slab specimens are shown in Fig. 16 and Fig. 17.

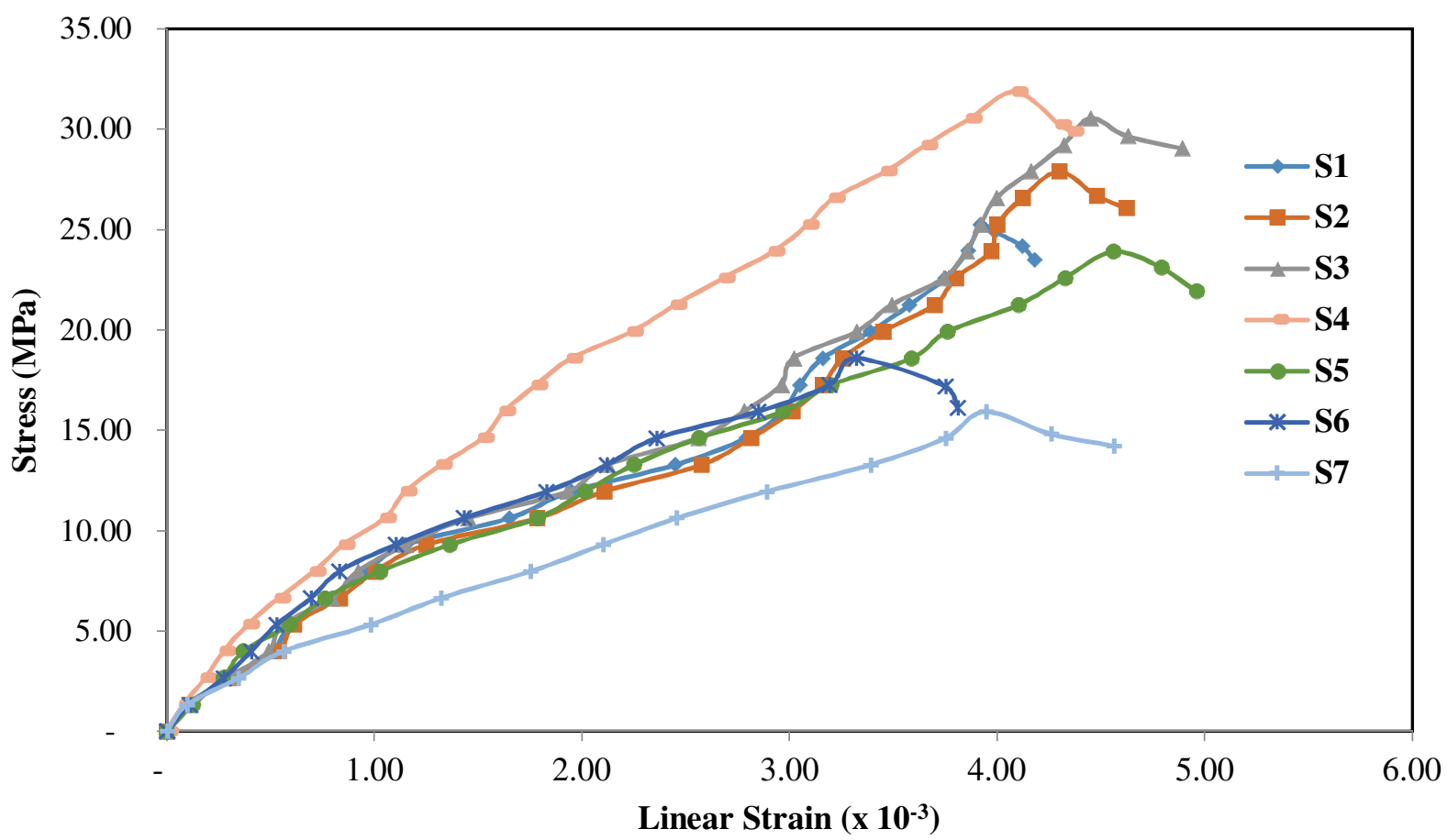

Fig. 14: Stress vs. linear strain behaviour of all slab specimens

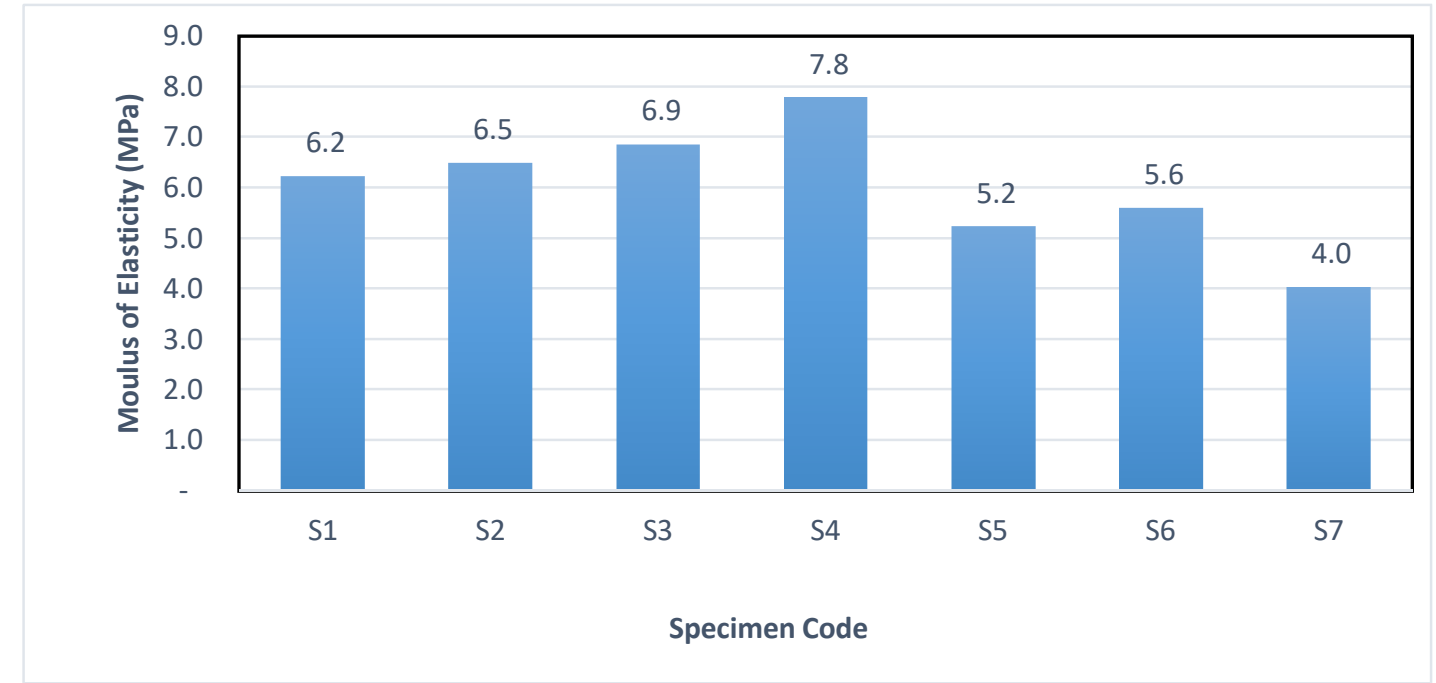

Fig. 15: Modulus of elasticity of one-way slabs 


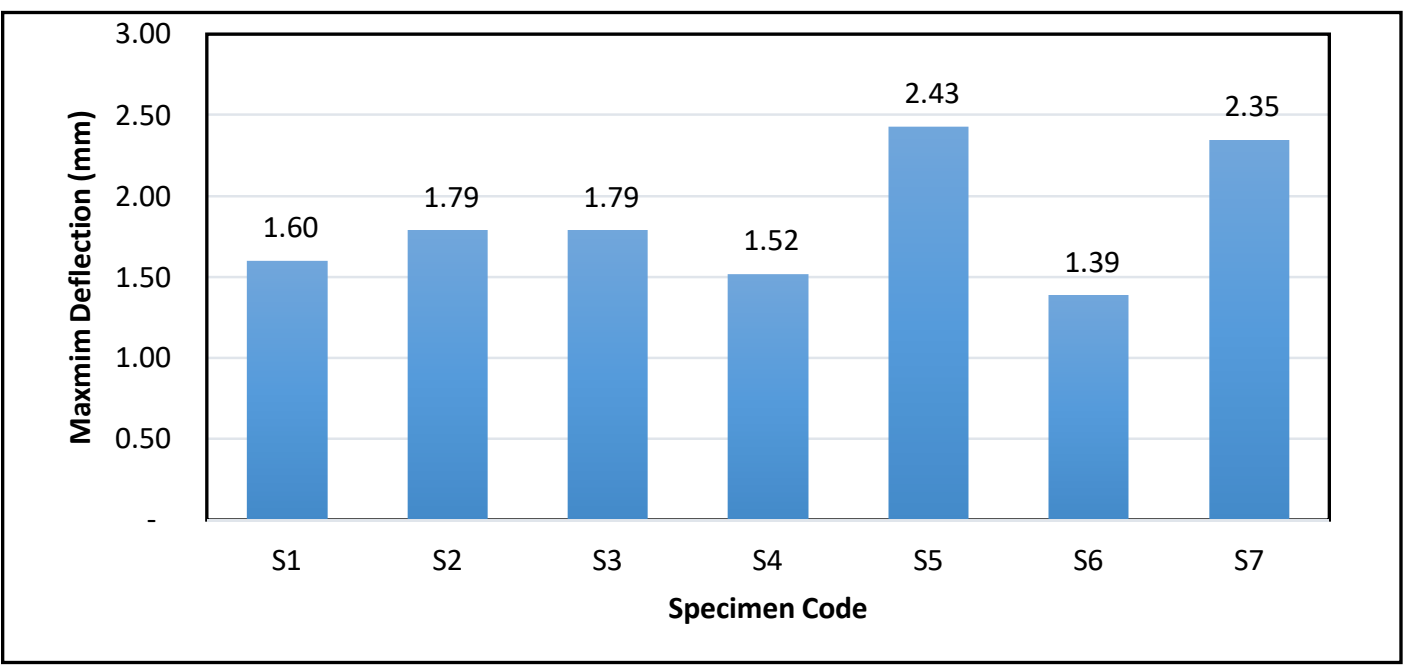

Fig. 16: Maximum deflection in one-way slabs

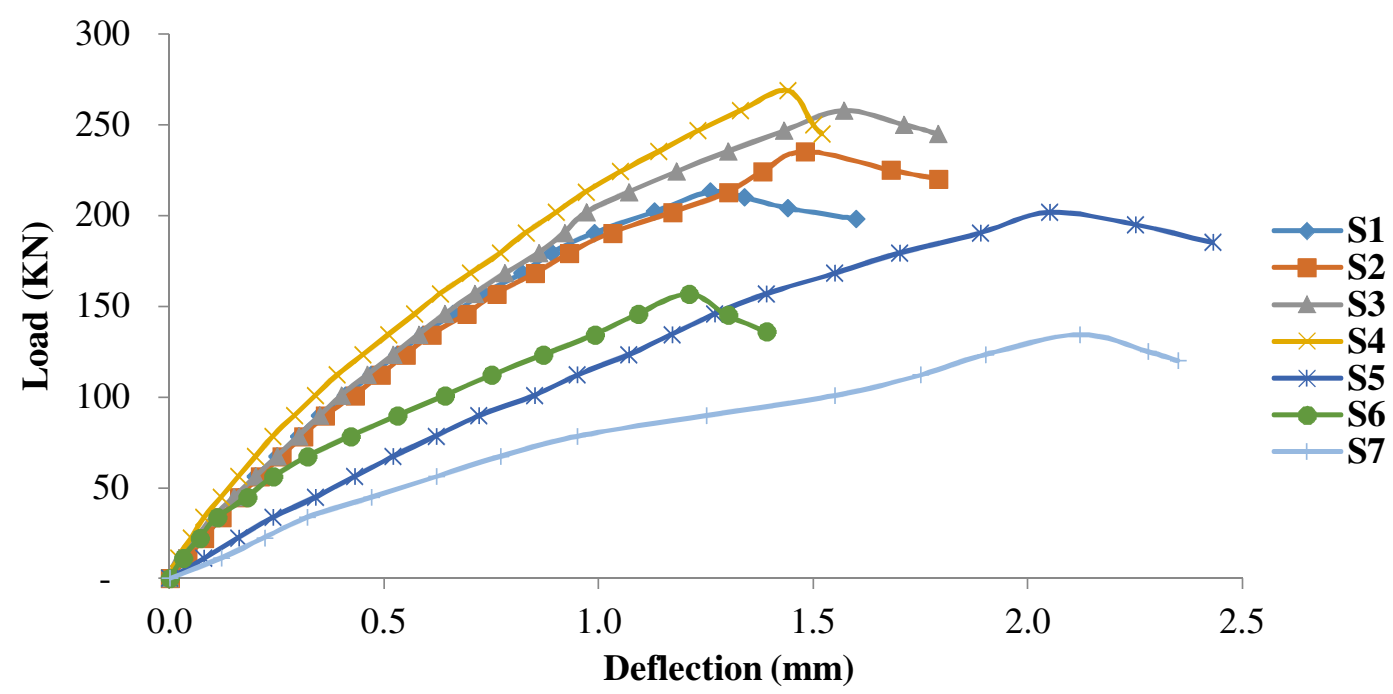

Fig. 17: Load vs. deflection behaviour of one-way slabs

With the addition of dosage of marble dust up to $7.5 \%$, decrease in the maximum deflection against the applied load was observed in S4 (7.5\% MD). Further addition of marble dust led to increase in the deflection. Maximum deflection in S1 (control slab) was recorded as $1.60 \mathrm{~mm}$ against the ultimate load. With the addition of marble dust the maximum deflection also increased to $1.79 \mathrm{~mm}$ in $\mathrm{S} 2(2.5 \% \mathrm{MD})$ and $1.79 \mathrm{~mm}$ in $\mathrm{S} 3(5 \% \mathrm{MD})$. But at replacement of $7.5 \%$ cement with marble dust in S4, 5\% decrease in maximum deflection as $1.52 \mathrm{~mm}$ against the ultimate load was observed. Further addition of dosage, resulted in increase of deflection as $2.43 \mathrm{~mm}$ in $\mathrm{S} 5$ (10\% MD), $1.39 \mathrm{~mm}$ in $\mathrm{S} 6$ (12.5\% MD) and $2.35 \mathrm{~mm}$ in S7 (15\% MD). Thus, ductility of RCC structures can be increased with the addition of marble dust and it can give warning before failure.

\subsubsection{Cracks pattern in RCC slabs}

After the application of load with the help of loading jack, cracks in the slab started to appear. Failure pattern was observed both in flexure and shear and is shown in Fig. 18 to Fig. 24. 


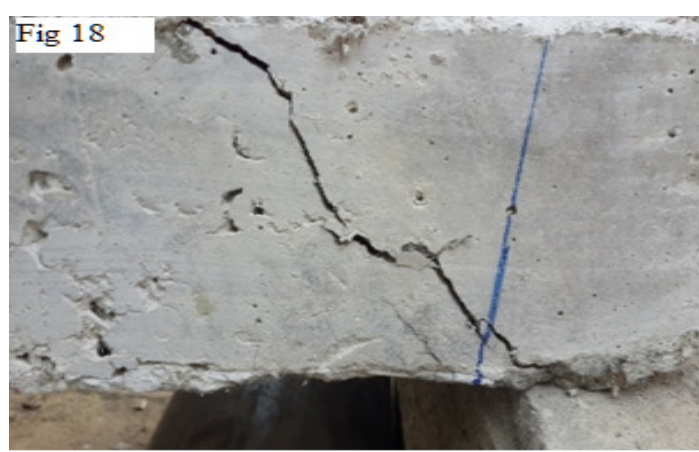

Fig. 18: Failure of control slab S1 in Flexure

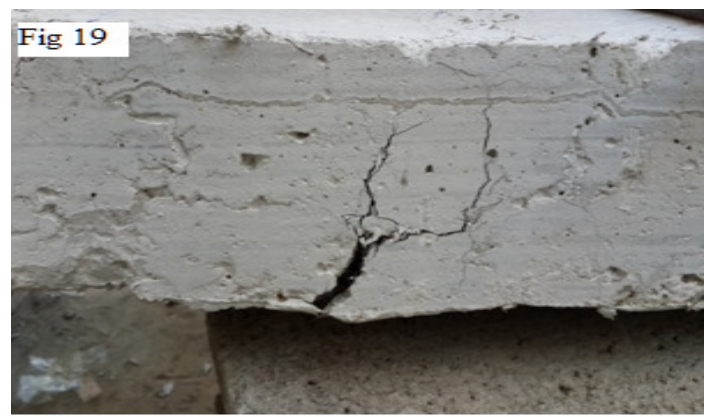

Fig. 19: Failure of slab S2 (2.5\% MD) in flexure and shear

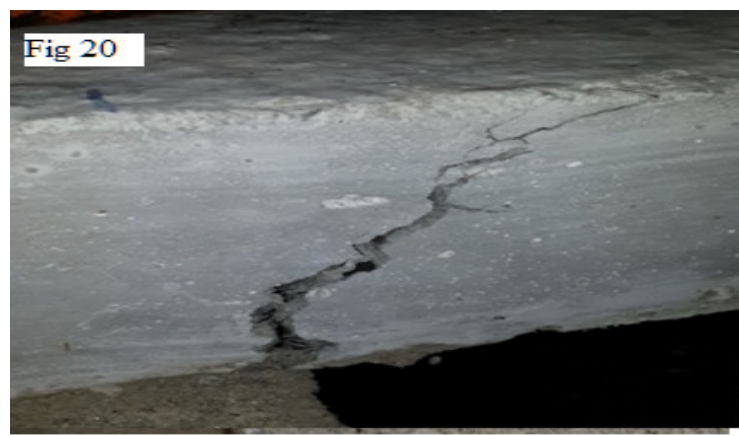

Fig. 20: Failure of slab S3 (5.0\%) in Flexure

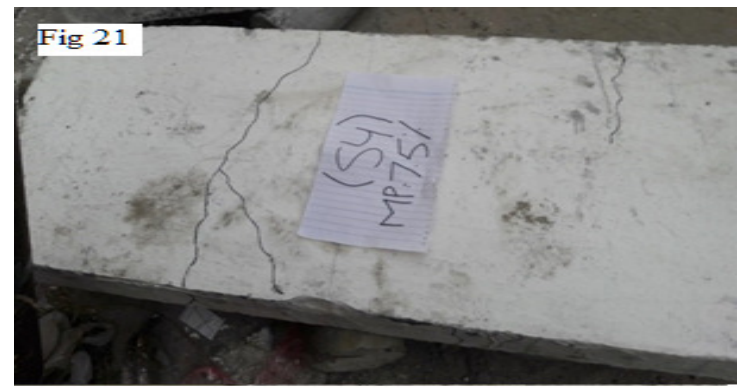

Fig. 21: Failure of Slab S4 (7.5\%) in Flexure and Shear

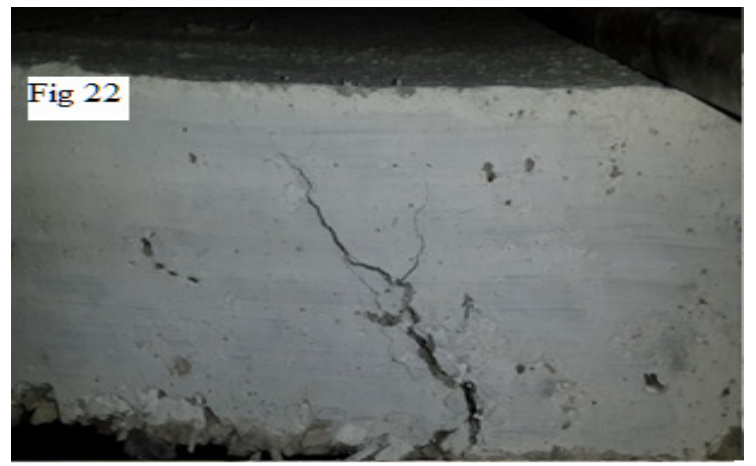

Fig. 22: Failure of slab S5 (10.0\% MD) in flexure

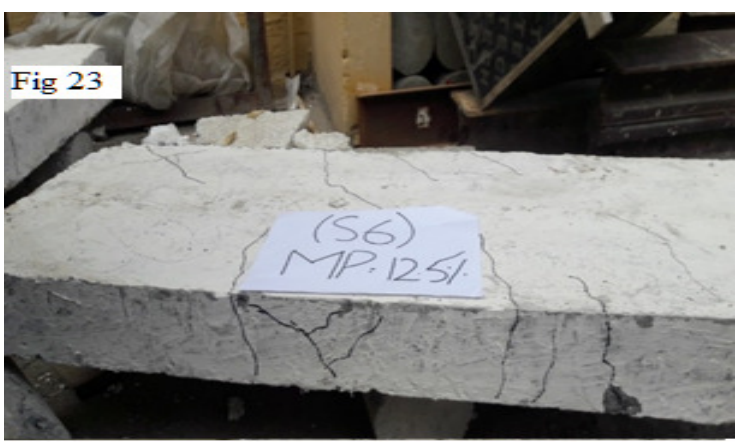

Fig. 23: Failure of slab S6 (12.5\% MD) in flexure and shear

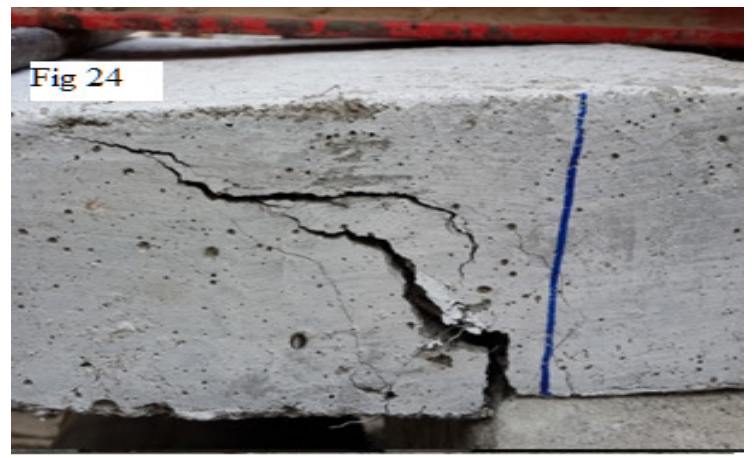

Fig. 24: Failure of slab S7 (15.0\% MD) in flexure

It can be seen from Figs. 18 to 24, that cracks pattern in all slab specimens followed a definite pattern. In Fig. 18 (control slab), pure flexural cracks of medium width $(1-2 \mathrm{~mm})$ were marked. In Fig. 19, S2 (2.5\% MD) shear and flexural cracks and in Fig. 20, S3 (5\% MD) only flexural cracks were observed. By increasing the dosage of marble dust up to $7.5 \%$ in Fig. 21 , both shear and flexural cracks were observed having width $<1 \mathrm{~mm}$. By further increase in the dosage of marble dust in Fig. 22, S5 (10\% MD), Fig.

Mehran University Research Journal of Engineering and Technology, Vol. 40, No. 4, October 2021 [p-ISSN: 0254-7821, e-ISSN: 2413-7219] 
23, S6 (12.5\% MD) and Fig. 24, S7(15\% MD), wide cracks having width $>2 \mathrm{~mm}$ in flexural and shear were observed. After the optimum dosage, bond strength became weak due to less amount of cement content that resulted in wider cracks.

\subsection{Ultrasonic pulse velocity test (UPV)}

The homogeneity and integrity of one-way slab specimens were predicted using Ultrasonic Pulse Velocity test (UPV) [15]. The UPV test conducted is shown in Fig. 25 and results of all RCC slab specimens are plotted in Fig. 26.

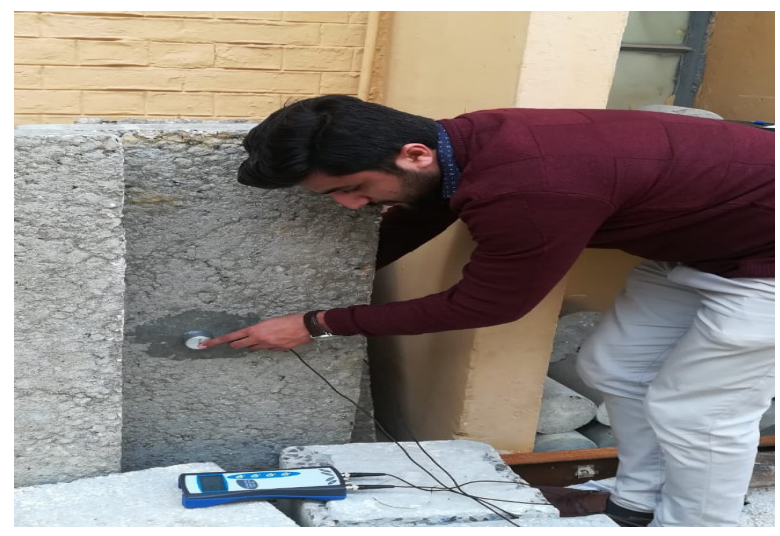

Fig. 25: UPV test being conducted on RCC slab specimen

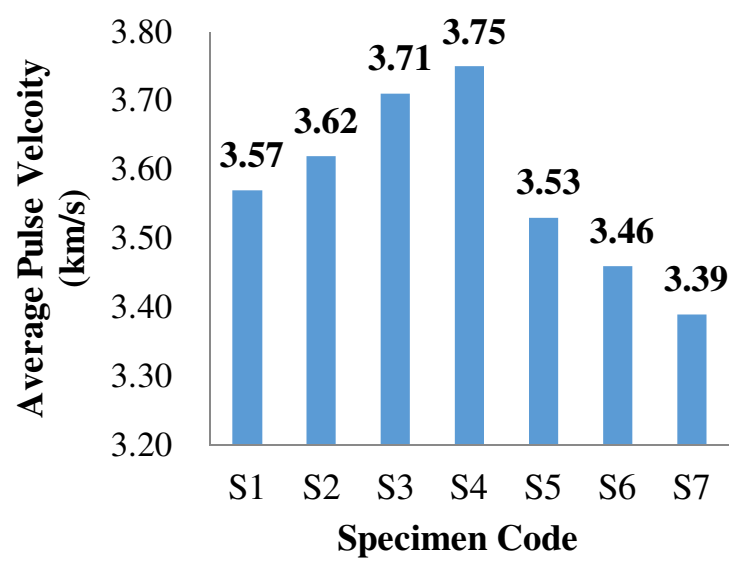

Fig. 26: Ultrasonic pulse velocity test results of oneway slabs

The highest average pulse velocity was recorded as $3.75 \mathrm{Km} / \mathrm{s}$ in $\mathrm{S} 4(7.5 \% \mathrm{MD})$ as compared to $\mathrm{S} 1$ (control slab). Higher value of pulse velocity means higher elastic modulus, indicating a stiffer structure. By increasing the dosage of marble dust as cement replacement in concrete up to $7.5 \%$, durability and structural properties of concrete were improved. Further addition of marble dust, led to decease in the average pulse velocity. The structure having higher UPV values are less subjected to corrosion and other atmospheric effects, because of greater stiffness.

\subsection{Chloride ion migration test}

One of the possible mechanisms of deterioration that ruins the durability, strength and service life of RCC structures is corrosion of steel reinforcement. The core roots of corrosion of steel reinforcement in concrete are chloride attack and carbonation transformation. The chloride ion migration test is much important regarding the durability and strength of RCC structures against the attack of chloride ions. Two Plain Cement Concrete (PCC) slabs of dimensions $304.8 \mathrm{~mm}$ x $304.8 \mathrm{~mm}$ x $114.4 \mathrm{~mm}$ were cast for each dosage of marble dust. Water cement ratio (w/c) was kept constant as 0.45 for all specimens. After 28 days, slabs were taken out from the curing tank and cores of size $100 \mathrm{~mm}$ dia and $114.4 \mathrm{~mm}$ length were extracted from each slab specimen with core cutter apparatus. With the help of marble saw cutter, sides of the cores were cut and a central piece of $100 \mathrm{~mm}$ dia and $50 \mathrm{~mm}$ thickness was taken out as a specimen and tested according to NT Build 492 standard, against the migration of chloride ions. The testing apparatus is shown in Fig. 27 and Fig. 28.

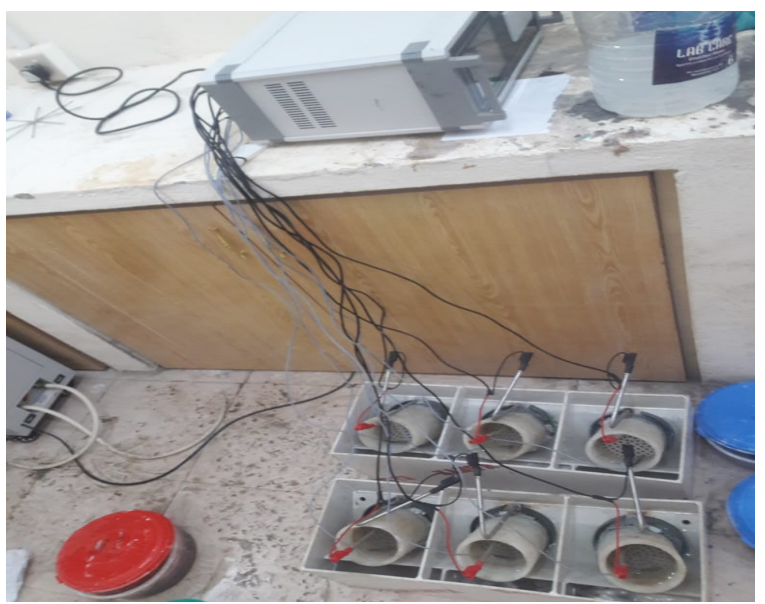

Fig. 27: Chloride ion migration test in progress

Mehran University Research Journal of Engineering and Technology, Vol. 40, No. 4, October 2021 [p-ISSN: 0254-7821, e-ISSN: 2413-7219] 


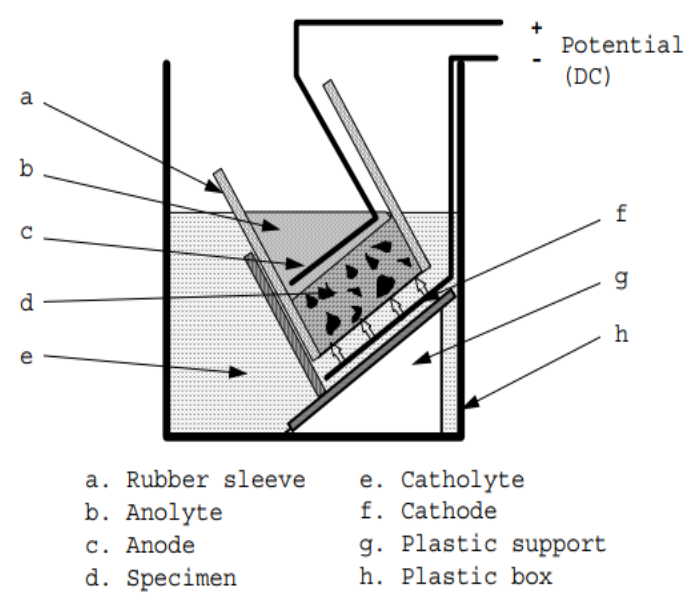

Fig. 28: Schematic apparatus for non-steady-state migration co-efficient

In this phenomenon, an electrical potential from the outside was applied axially through the specimens that compelled the migration of external chloride ions into the concrete specimens. After 24 hours duration, the specimens were split axially and solution of silver nitrate was sprayed on the split sections. After spray, visible white silver chloride precipitations were formed on the surface and chloride penetration depth was directly measured with the help of scale. The chloride ion migration co-efficient was calculated from Formula B [16].

$\mathrm{D}_{\mathrm{nssm}}=\frac{0.0239(273+\mathrm{T}) \mathrm{L}}{(\mathrm{U}-2)^{\mathrm{t}}}\left(\mathrm{x}_{\mathrm{d}}-0.0238 \sqrt{\frac{(273+\mathrm{T}) \mathrm{Lx}}{\mathrm{U}-2}}\right)$

In the above formula (B), non-steady-state migration co-efficient $\left(\times 10^{-12} \mathrm{~m}^{2} / \mathrm{s}\right)$ is denoted by $D_{\text {nssm. }}$. Initial and final temperature readings $\left({ }^{\circ} \mathrm{C}\right)$ of anolyte solution were noted down and their average was taken as $\mathrm{T}$. Voltage (V) was applied and its absolute value taken as U. Similarly, $\mathrm{L}$ is the thickness of the specimen $(\mathrm{mm}), \mathrm{x}_{\mathrm{d}}$ is average value of penetration depth $(\mathrm{mm})$ and $t$ is the duration of test (hours).

The Catholyte is solution of $10 \% \mathrm{NaCl}$ by mass in tap water and anolyte is solution of $0.3 \mathrm{~N} \mathrm{NaOH}$ in distilled water. Cathode connected to the positive terminal and anode connected to the negative terminal of power supply. $D_{\text {nssm }}$ values were calculated by Formula (B) and the results are plotted in Fig. 29.

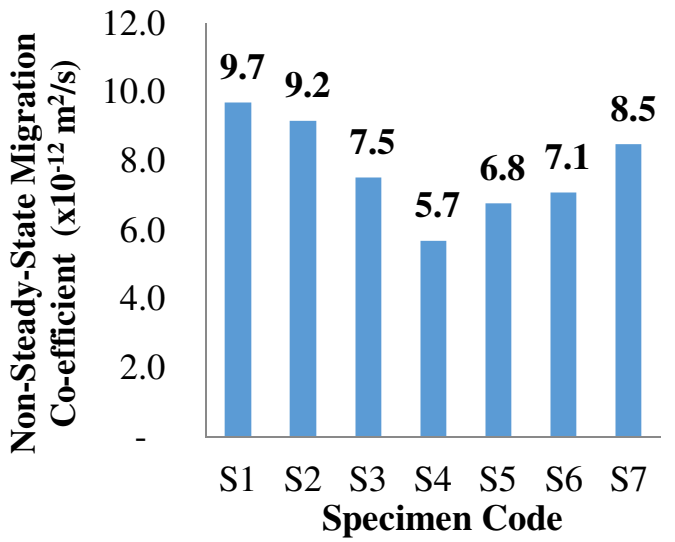

Fig. 29: Chloride migration co-efficient for all concrete mixes

It was found out that in S1 (control specimen) nonsteady-state migration co-efficient was 9.7 and it started decreasing up to 5.7 in S4 (7.5\% MD). Further addition of marble dust led to increase in the chloride ion migration co-efficient. The reason was that addition of marble dust resulted in higher resistance to migration of chloride ions as compared to the control specimen i.e. $100 \%$ cement concrete. The increase of resistance to chloride ion migration was due to micro sized marble dust particles. These micro sized particles contributed to a higher compactness of the mix by filling all the voids. Due to this, migration of chloride ions was blocked, resulted in lower values of migration co-efficient.

\subsection{Cost comparison}

For a mega project where thousands of cubic meter concrete is required, cost can be saved efficiently by cement replacement with marble dust. Cost comparison between ordinary concrete and 7.5\% marble dust concrete for different classes of concrete, according to National Highway Authority of Pakistan (NHA) is shown graphically in Fig. 30.

The cost comparison was done by taking weights of all materials of concrete i.e. cement, aggregates, water and admixtures, required for one cubic meter of concrete, for each concrete class. The weights of each ingredient were then multiplied with their market price that gave cost of concrete per cubic meter. The most

Mehran University Research Journal of Engineering and Technology, Vol. 40, No. 4, October 2021 [p-ISSN: 0254-7821, e-ISSN: 2413-7219] 
commonly used class is A1 (21 MPa), for 100 cu.m concrete we can save an amount up to 123,300 PKR approximately. This margin of cost saving increases as we further move to high strength concrete class i.e. Class A2 (24 MPa), Class D2 (35 MPa) etc.

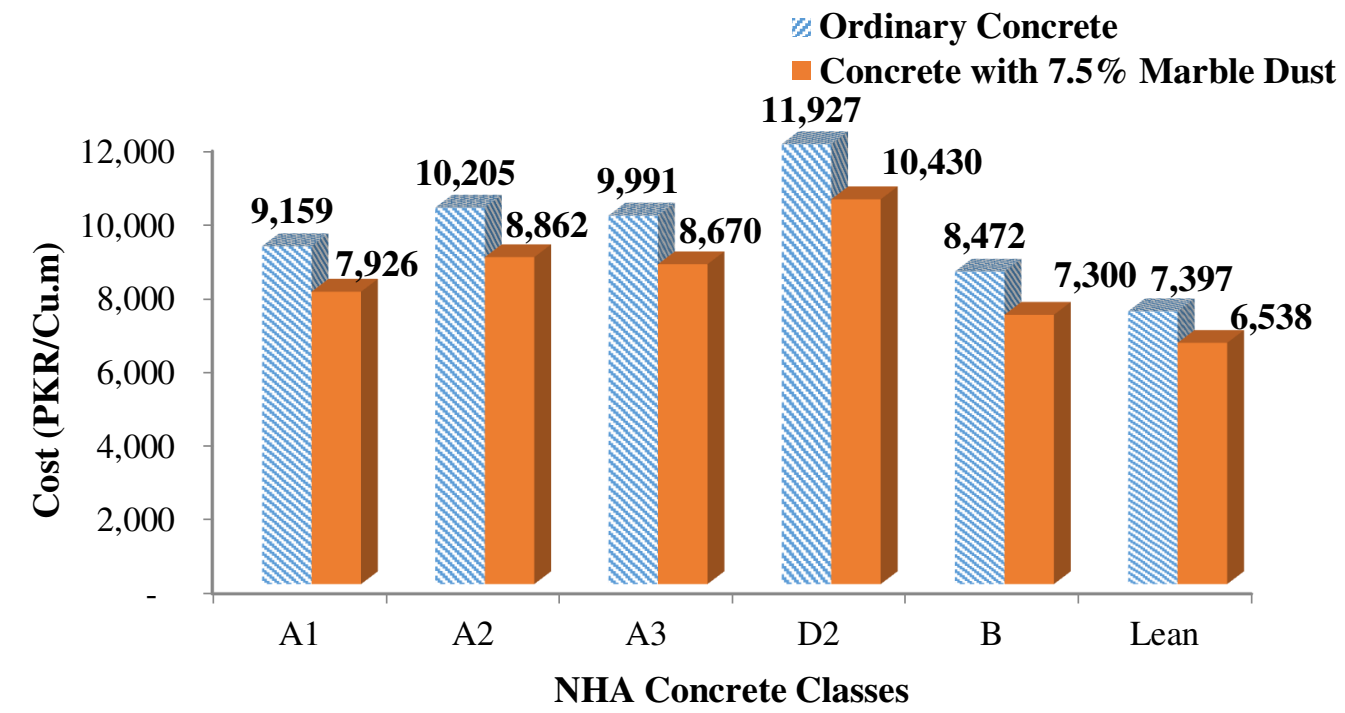

Fig. 30: Cost of ordinary concrete vs. concrete with marble dust

\section{CONCLUSIONS AND RECOMMENDATIONS}

\subsection{Conclusions}

From the above experimental research, following conclusions can be summarized.

1. Workability of the concrete mix decreases with the addition of the marble dust content. Thus, addition of marble dust reduces the concrete bleeding and controls segregation of the mix. However, admixtures can be used to achieve required slump.

2. Addition of marble dust as cement replacement material, increases the compressive strength of concrete up to a certain limit. Marble dust up to $7.5 \%$ replacement of cement can be done in order to achieve high compressive strength. Further addition leads to decrease in compressive strength.

3. Addition of marble dust as cement replacement material, increases the split tensile strength of concrete up to a certain limit. Maximum split tensile strength can be achieved up to $7.5 \%$ replacement of cement with marble dust. Further increase of dosage of marble dust, decreases its split tensile strength.

4. Addition of marble dust as cement replacement material, improves the permeability of the concrete. Up to $10 \%$ cement replacement with marble dust can be done for non-porous and impermeable concrete. Further addition of marble dust, increases the porosity that results in increase of permeability of concrete.

5. Resistance of concrete against corrosion of steel reinforcement can be increased by using $7.5 \%$ marble dust, replaced with cement. At $7.5 \%$ dosage least chloride ion migration co-efficient was observed (mainly responsible for corrosion of steel reinforcement) as compared to control mix. Attack of chloride ions can be minimized by using marble dust in concrete.

6. For RCC structures i.e. one-way slabs, addition of marble dust decreases the deflection in slabs against the applied load up to $7.5 \%$ dosage. Moreover, structural load bearing capacity also increases up to $7.5 \%$ replacement of cement with marble dust. At this dosage, minimum deflection and strain was recorded. Cement up to $7.5 \%$ 
replacement of marble dust makes one-way slab more stiffer (more modulus of elasticity) as compared to control slab.

7. Economical concrete can be produced, as economy is saved and solid waste materials are utilized in the concrete.

8. UPV values of one-way slab show that increasing dosage of marble dust up to $7.5 \%$ replacement of cement, increases its modulus of elasticity, density and makes it stiff that is less subjected to corrosion and other atmospheric changes.

\subsection{Recommendations}

It is recommended to use marble dust in RCC Oneway slab, as it has great positive influence on the structural properties of concrete. However, dosage of marble dust as replacement of cement might be increased or decreased depending upon the purpose and use of concrete.

\section{ACKNOWLEDGEMENT}

The authors gratefully acknowledge the assistance provided by the University of Engineering and Technology, Taxila for the casting as well as testing of all specimens. Authors are also thankful to the staff of concrete and environmental engineering labs of UET Taxila, who fully assisted in completing this research.

\section{REFERENCES}

1. "All Pakistan Cement Manufacturer Association, "Historical Analysis of Cement Production Capacity and Despatches (Operational Units Data)", data taken of last ten years from 2008 2018.

https://www.apcma.com/data_history.html [Last accessed on 24th March 2019].

2. "The Express Tribune Business, "Cement Sales Continue to Grow Amid Strong Demand", Published on May 6, 2018, https://tribune.com.pk/story/1703345/2-julyapril-cement-sales-continue-grow-amid-strongdemand-business/ [Last accessed on $26^{\text {th }}$ June 2019].
3. News Desk, "Pakistan's World of Cement: Opportunities and Challenges", Published on April 12, 2018, https://www.globalvillagespace.com/pakistansworld-of-cement-opportunities-and challenges/. [Last accessed on $1^{\text {st }}$ July 2019].

4. Jadoon S., Amin A.F.A., Malik A., Kamal H., "Soil Pollution by the Cement Industry in the Bazian Vicinity, Kurdistan Region", Journal of Environmental \& Analytical Toxicology, Vol. 6, No. 6, p. 1, 2016.

5. Ahmed M.L., Javed M.A., Qureshi A.S., "Benefits of Incorporating Induction Furnace Slag in Concrete as Replacement of Cement: A Case Study of Pakistan", Mehran University Research Journal of Engineering and Technology, Vol. 37, No. 4, pp. 701-714, October 2018.

6. Dewangan D.A., Gupta D.D.P., "Signifcance of Marble and Portland Cement", Internatioal Journal of Engineering Technologies \& Management Research, Vol. 5, No. 2, pp. 255265, February, 2018.

7. Mangi S.A., Jamaluddin N.B., Siddiqui Z., Memon S.A., Ibrahim, M.H.B.W., "Utlization of Sawdust in Concrete Masonary Blocks: A Review", Mehran University Research Journal of Engineering and Technology, Vol. 38, No. 2, pp. 487-494, April 2019

8. Arshad A., Shahid I., Anwar U.H.C., Baig M.N., Khan S., Shakir K., "The Wastes Utility in Concrete", International Journal of Environmental Research, Vol. 8, No. 4, p. 1323, April 29, 2014.

9. Khaliq S.U, Shahzada K., Alam B., Bilal F., Zeb M., Akbar F., "Marble Powder's Effect on Permeability and Mechanical Properties of Concrete", International Journal of Civil \& Environmental Engineering, Vol. 10, No. 4, p. 537, May, 2016.

10. Sharma E.G.P., Singhal D.D.K., "Feasibility of Marble Waste Utilization in Buildings to Save Environment", International Journal of Emerging Trends in Science and Technology, Vol. 4, No. 6, p. 5301, June 30, 2017.

11. "Marble and Granite Sector Brief, "Small and Medium Enterprise Development Authority 
(SMEDA)", Government of Pakistan, Chapter 3, p. 7, Revised on July 12, 2002, www.smeda.org.pk.

12. ACI Committee 211, "Standard Practice for Selecting Proportions for Normal, Heavyweight and Mass Concrete (ACI 211.1-91)", 2002.

13. ASTM International, "Standard Test Method for Flexural Strength of Concrete (Using Simple Beam with Centre-Point Loading), Designation C 293-02”, April 2002.

14. ASTM International, "Standard Test Method for Compressive Strength of Cylindrical Concrete Specimens, Designation: C 39/C 39M - 03”. Reapproved July, 2003.

15. ASTM International, "Standard Test Method for pulse velocity through concrete, Designation: C 597 - 02", February, 2003.
16. Nordtest Method, "Concrete, Mortar and Cement Based Repair Materials: Chloride Migration Coefficient from Non-Steady-State Migration Experiments", NT Build 492, ISSN 0283-7153, Published by NORDTEST, Finland, Approved 1999-2011.

17. ASTM International, "Standard Test Method for Split Tensile Strength of Cylindrical Concrete Specimens, Designation: C 496/C 496M-04". Reapproved February, 2004. 